\title{
Determination of PCDD/F and DL-PCB pollution levels, source appointment and risk assessment of surface sediments in dam lakes in Istanbul, TURKEY
}

\section{Oltan CANLI}

TUBITAK Marmara Research Centre: Tubitak Marmara Arastirma Merkezi

Barş GÜZEL ( $\square$ guzelbaris08@gmail.com )

TUBITAK Marmara Research Centre: Tubitak Marmara Arastirma Merkezi https://orcid.org/0000-0002-6709-2339

\section{Aykan KARADEMIR}

Kocaeli University: Kocaeli Universitesi

\section{Research Article}

Keywords: Dam Lake, DL-PCBs, PCDD/Fs, Istanbul, Surface Sediment, Risk Assessment

Posted Date: February 25th, 2022

DOI: https://doi.org/10.21203/rs.3.rs-1317650/v1

License: (c) (i) This work is licensed under a Creative Commons Attribution 4.0 International License. Read Full License 


\section{Abstract}

The current situation of the water resources of Istanbul, which is one of the important metropolises of Europe, should be known and constantly monitored by the reasons of the rapid increase in the city population, the acceleration of production-related industrial activities, the expansion of the city with construction activities and the decrease in precipitation. The purpose of this study was to reveal the situations of surface sediments collected from Istanbul water reservoirs in terms of PCDD/Fs and DL-PCBs, to identify possible sources, and to conduct their ecological risk assessment. Total PCDD/Fs and DL-PCBs concentrations varied between 28.13-447.13 pg/g (average $136.75 \mathrm{pg} / \mathrm{g}$ ) and $12.19-340.05 \mathrm{pg} / \mathrm{g}$ (average $72.09 \mathrm{pg} / \mathrm{g}$ ). Corresponding TEQ values of PCDD/Fs and DL-PCBs were between 0.53-5.37 pg TEQ/g (average $2.23 \mathrm{pg} \mathrm{TEQ} / \mathrm{g}$ ) and $0.02-0.44 \mathrm{pg} \mathrm{TEQ} / \mathrm{g}$ (average $0.12 \mathrm{pg} \mathrm{TEQ} / \mathrm{g}$ ), respectively. OCDD is the dominant congener by constituting about $75 \%$ of the total PCDD/Fs on average, while congener distributions of DL-PCBs showed the dominance of PCB-118 and PCB-105. The sediments taken from Kazandere dam have the lowest pollution levels for both PCDD/Fs and DL-PCBs. The highest PCDD/F and DL-PCB amounts were measured in sediments of Alibey and Elmalı dams (closest to highly populated settlements of Istanbul), which are most affected by the air pollution caused by the traffic and combustion for residential heating. Almost all the sediments have total dioxin-like toxicity levels higher than the safe threshold level (with two exceptions) of $0.85 \mathrm{pg} \mathrm{TEQ} / \mathrm{g} \mathrm{dw}$, proposed for ecological risk. Health risk assessment shows that levels of dioxin-like compounds would result in a total intake of $0.33 \mathrm{pg} \mathrm{TEQ} / \mathrm{kg}$ bw/day even in the worst-case scenario, not exceeding the tolerable daily intake value of $1 \mathrm{pg}$ TEQ/kg bw/day. Among exposure pathways, consumption of fish constitutes almost all the total intake, while contributions of other pathways are minimal.

\section{Introduction}

Polychlorinated dibenzo-p-dioxins (PCDDs), polychlorinated dibenzofurans (PCDFs), and dioxin-like polychlorinated biphenyls (DL-PCBs) are carbon-based persistent organic substances containing a large amount of chlorine as an involuntary by-product of industrial and combustion processes (Field and Sierra-Alvarez, 2008; Kulkarni et al., 2008). Non-biodegradability (Wang et al., 2016), atmospheric transport over long distances (Li et al., 2007), biomagnify in food chains (Shaw et al., 2014) and accumulation in the adipose tissues of living things (Güzel et al., 2020) are the most important chemical characteristics that provide permanence to these substances in the environment. Their existence in various environments (air, soil, water, sediments, foods etc.) is of concern due to their significant health effects including carcinogenic toxicity. Sediments, fine-grained layer on the bottom surfaces of the water bodies, are formed by the sedimentation of the particles resulting from several human and natural activities such as erosion, surface water and sewage discharges, agricultural practices etc. (Güzel et al., 2021). Since the formation of the sediments is generally a very slow process taking decades, they are known as the final sinks of the pollutants released to the environment and could be used for studying pollution history. Polluted sediments, on the other hand, pose significant health risks through the pollutant transfer mechanisms between sediment-water-biota. Even very low concentrations of organic pollutants (OPs), such as polycyclic aromatic hydrocarbons (PAHs), polybrominated diphenyl ethers (PBDEs), organochlorine pesticides (OCPs), PCBs, PCDD/Fs, in sediments can cause toxic, carcinogenic and mutagenic reactions for living organisms (Jaishankar et al., 2014; Dinç et al., 2021). As the atmospheric transportation is the main action of the accumulation of these substances in the environment, then they are transferred to the aquatic environment through dry and wet deposition, and they tend to partition, degradation and transportation. As a result, the transition of pollutants to the lower layers in the sediment becomes easier and the concentrations of pollutants in aquatic organisms increase rapidly (Nguyen et al., 2005; Evenset et al., 2007). PCDD/Fs and DL-PCBs have low Henry constants and high log $\mathrm{K}_{\text {ow }}$ values (octanol/water distribution coefficient), so they are easily adsorbed in soils and sediments (Hung et al., 2017) and over time, their bioaccumulation has become a worldwide problem (Sany et al., 2015; Suzuki et al., 2016; Lin et al., 2017). Some studies have been conducted in the last decade regarding the level, the number and the variety of PCDD/Fs and DL-PCBs pollution in lake sediments of different parts of the world. For instance, Nunes et al. (2011) investigated the contamination levels of 17 PCDD/Fs, and 12 DL-PCBs in sediment and biota from the Mondego estuary (Portugal). The concentration on a dry weight basis of sediment was determined as $109.68 \mathrm{pg} / \mathrm{g}$ for total PCDD/Fs and $199.23 \mathrm{pg} / \mathrm{g}$ for total dl-PCBs. Sanctorum and co-workers (2017) carried out a study for the assessment of pollution levels of PAHs, PCDD/Fs and non-ortho PCBs in Yser and Upper-Scheldt river sediments (transboundary rivers (Belgium-France)). The maximum concentrations for PCDD/Fs and non-ortho PCBs were found to be $12 \mathrm{ng}$ TEQ/kg and $5.1 \mathrm{ng} T E Q / \mathrm{kg}$, respectively. In Korea, the study has been done on possible severe pollution of PCDD/Fs and DL-PCBs in sediments from Lake Shihwa, and from creeks that discharge into this artificial lake. Total concentrations of PCDD/Fs and DL-PCBs in sediments were reported ranging from 0.04 to $100 \mathrm{ng} / \mathrm{g}$ dry weight and from 0.05 to $335 \mathrm{ng} / \mathrm{g}$ dry weight, respectively (Moon et al., 2012). In another study, the concentrations of PBDEs, PCBs and PCDD/Fs were determined in the sediment samples collected from seven major river basins (Yellow River, Yangtze River, Pearl River, Haihe River, Tarim River, Ertix River, and Liaohe River) around China. Their concentrations ranged from 0.29 to $21.7 \mathrm{ng} / \mathrm{g}$ dry weight and from 0.01 to $6.49 \mathrm{ng} / \mathrm{g}$ dry weight for PCBs and PCDD/Fs (Wang et al., 2016). The study in Belgium was performed for the determination of the spatial and time trends of concentrations of PCDD/Fs and DL-PCBs in sediment samples from the North Sea Coast and the Scheldt River basin up to Temse (situated $98 \mathrm{~km}$ from the mouth). The concentrations of PCDD/Fs and DL-PCBs in sediments were explained varying from 0.55 to $21.5 \mathrm{pg}$ $\mathrm{T}(\mathrm{B}) \mathrm{EQ} / \mathrm{g}$ dry weight and from 0.13 to $3.40 \mathrm{pg} \mathrm{T}(\mathrm{B}) \mathrm{EQ} / \mathrm{g}$ dry weight (Vandermarken et al., 2018). 
The aim of this study was to assess the pollution levels in the surface sediments collected from Istanbul water reservoirs in terms of PCDD/Fs and DL-PCBs, to identify the possible sources, and to conduct their ecological risk assessment. It is the first study conducted in Turkey on the PCDD/Fs and DL-PCBs pollution levels of either the sediments of Istanbul water resources or the sediments of other reservoirs. In addition, since there are very few similar studies in the world, it is thought that it will make important contributions to other studies in the world.

\section{Materials And Methods}

\subsection{Description of sampling region and study}

Istanbul has always been one of the most important cities in Europe from past to present. It has turned into a metropolitan city by entering a serious growth trend with the rapid increase in the city population, the acceleration in production-related industrial activities, and the expansion of the city with construction activities. Thus, it is home to a population of approximately 20 million, together with the migrations due to the political instabilities in the neighbouring countries in recent years. Therefore, great water demand of such high population living in the city together with the decrease in precipitation due to the climate change started to have a serious impact and pressure on the city water resources, especially after 2005. This situation has been somewhat reduced by the fact that new dams and reservoirs have been built in the city over the years and the water supplied from the dams of neighbouring cities (Altınbilek, 2006; Ünalan, 2011). A small part of the city's total water consumption is supplied from underground water resources (30 million $\mathrm{m}^{3}$ per year), while a significant portion of the total consumption is supplied from surface water reservoirs (1660 million $\mathrm{m}^{3}$ of water per year) (ISKI, 2021; Baban et al., 2011). About half of the surface waters supplied to the city are stored in Terkos, Alibey, Büyükçekmece, Papuçdere, Kazandere, Sazlıdere dams and Istranca (Düzdere dam, Kuzuludere dam, Büyükdere dam, Sultanbahçedere dam, Elmalıdere dam) on the European side, and Ömerli, Darlik and Elma dams on the Asian side, while the second half comes from the reservoirs and rivers (mainly Melen River) outside of Istanbul (ISKI, 2021),

The sampling of the surface sediment from the reservoirs and dams that supply water to Istanbul was carried out between October 12,2020 October 14, 2020, using a $0.1 \mathrm{~m}^{2}$ Van Veen sediment grab ladle held from the Zodiac boat. Each sample was taken from approximately $5 \mathrm{~cm}$ depth of the top layer of the surface sediment using a stainless-steel grub and was filled in a $250 \mathrm{ml}$ glass jar without any air. Sampling standards for PCDD/F and DL-PCBs were added to the samples separately during sampling. The locations of the sampling points are shown in Fig. 1 and the location information of these sampling points are given in Table 1. The transfer of sediment samples to the relevant laboratories was done by a vehicle with a cooling system including ice coolers to $-20^{\circ} \mathrm{C}$.

[Figure 1 near here]

[Table 1 near here]

\subsection{Reagents and chemicals}

$\mathrm{N}$-nonane was purchased from Acros Organics (New Jersey, USA). Acetone, diethyl ether, dichloromethane, ethanol, n-hexane, methanol, toluene, tetradecane and petroleum ether were supplied from Merck (Darmstadt, Germany). All organic solvents used in the analysis were of analytical grade (90-99.9\% purity range). P48-W-CS1, CS2, CS3, CS4, CS5 PCDD/F calibration solutions, EN-1948SS PCDD/F sampling solution, EN-1948ES PCDD/F extraction solution, EN-1948IS PCDD/F syringe solution, P48-W-CVS WHO dl-PCB calibration solutions, P48-WSS WHO dl-PCB sampling solution, P48-W-SS WHO DL-PCB sampling extraction and P48-RS mass-labelled DL-PCB recovery solution in amber glass flame-sealed ampoules $(0.5 \mathrm{~mL})$ were bought from Wellington Laboratories (Guelph, Canada). The Supelco Dioxin Prep System was used for the clean-up process. Silica gel from Merck (70-230 mesh) (0.063-0.2 mm) (Darmstadt, Germany) and florosil from Supelco (60/100 mesh) (Bellefonte, U.S.) as powder form were purchased. Both high purity $(99.99 \%)$ nitrogen and helium were used as carrier gases for HR-GC/MS.

\subsection{Sample preparation and analytical instrumentation}

The surface sediment samples in glass jars filled to the brim were homogenized and transferred to drying vessels and kept in Teknosem brand lyophilizer until it completely lost their water contents. The samples, which were separated from plastic, paper, large stones, etc., with the help of a sieve, were ground in an agate mortar. For PCDD/F and DL-PCB analysis, $10 \mathrm{~g}$ of dried samples were weighed into the extraction cartridge. Extraction standards for PCDD/F and DL-PCBs were added to the samples separately prior to extraction. In pursuant to the EPA $3540 \mathrm{C}$ Soxhlet extraction method, PCDD/Fs and DL-PCBs in the samples were collected completely with toluene in heat-resistant glass containers for 8 hours. After extraction processes, approximately $230 \mathrm{~mL}$ of extracts was obtained and were concentrated to $0.5 \mathrm{ml}$ by passing through nitrogen gas with the help of Zymark nitrogen gas evaporator. PCDD/F and DL-PCBs were clean-up with the multilayer silica column and florisil column in the Supelco Dioxin Preparation System, with $10 \mathrm{~mL}$ of hexane to the remaining volume. DL-PCBs were easily collected from the silica column with hexane, whereas PCDD/Fs were retained on the florisil column. $10 \mu$ l of tetradecane was added to the 
DL-PCBs in hexane and evaporated in the Zymark nitrogen gas evaporator. Finally, $20 \mu \mathrm{l}$ of DL-PCB syringe standard and $20 \mu \mathrm{l}$ of nonane were added to them, and they were put to the insert in the vial and made ready for analysis. The florisil column adsorbed PCDD/Fs was washed with $50 \mathrm{~mL}$ of dichloromethane and was collected in the vessel in the vacuum manifold. The dichloromethane in the extract was evaporated until it evaporated completely and $20 \mu \mathrm{l}$ of PCDD/F syringe standard was added and put in the insert. The amounts of PCDD/Fs and DL-PCBs were carried out in High Resolution (HR)-GC/MS in compliance with the isotope dilution technique.

The determination of PCDD/F and DL-PCB quantities in the samples was carried through with an Agilent Technologies 6890N Network GC system (Avondale, USA) equipped with Waters Micromass AutoSpec Premier HR-MS detector (Waters, USA) in electron impact ionization (EI+ mode) at a resolution of $>10,000$. Data analysis and processing of PCDD/Fs and DL-PCBs were done using MassLynx V4.1 and Quan Lynx V4.1 softwares. A DB-5MS fused silica capillary column (60 m length, $0.25 \mathrm{~mm}$ i.d., $0.25 \mathrm{~mm}$ film thickness, $5 \%$ phenyl / $95 \%$ methyl silicone, J\&W Scientific, Folsom, CA, USA) was used in their GC analysis. The optimized GC program for the qualification and quantification of PCDD/Fs and DL-PCBs is exhibited in Table 2.

[Table 2 near here]

Table S1 in supplementary material demonstrates the optimal HR-GC/MS conditions for the determination of PCDD/Fs and DL-PCBs, such as retention time (RT) and analyte-bound ions (target ion and precursor ions). Collision energy voltage was set at $45 \mathrm{~V}$. MS data were acquired in the positive ion mode using HR/MS scan event. The confirmation of all compounds in HR-GC/MS was actualized by comparing the ion ratios and retention times with corresponding standards in the chromatograms.

\subsection{Quality assurance, quality control}

Auto-tune of MS on the HR-GC/MS instrument was carried out in compliance with the criteria using per-fluorokerosene (PFK) to check the instrument stability and resolution of different masses of PCDD/Fs and DL-PCBs for the optimum sensitivity conditions of the instrument prior to starting the analysis of the samples. Throughout the entire study, utmost care was taken to meet the quality control and quality assurance requirements. As Song et al. (2022) stated in their study, the following three criteria were taken into account for each substance of PCDD/Fs and DL-PCBs in this study as well: (a) Compounds in the sample were within \pm 0.1 min deviation limits when compared to the related standards (Fig. 2) that matched their GC retention times; (b) signal-to-noise (S/N) ratios $\geq 10$; (c) isotopic ion ratios are found within $20 \%$ of the theoretical values. The evaluation of the performance of cleaning procedures was made by the calculation of the recovery of ${ }^{13} \mathrm{C}_{12}$-labeled ISs of PCDD/Fs and DL-PCBs added to all samples. The average recoveries \pm standard deviation (ranges) of PCDD/Fs and DLPCBs were $62 \pm 19 \%$ (30-149\%) and $74 \pm 17 \%$ (40-130\%), respectively. All glassware and necessary apparatus to be used in the analysis as procedural blank were thoroughly washed with dichloromethane to reveal background contamination and the same cleaning procedure was applied as the surface sediment samples. Most of the target analytes were not detected and very few number of analytes were found below the quantification limits (LOQs, S/N < 10, PCDD/Fs: $0.03-0.14 \mathrm{pg} / \mathrm{g}$; DL-PCBs: $0.04-0.10 \mathrm{pg} / \mathrm{g}$ ) in the procedural blanks. The recoveries of ${ }^{13} \mathrm{C}_{12}$-labeled ISs of PCDD/Fs and DL-PCBs varied from $44-117 \%(72 \pm 26 \%)$.

[Figure 2 near here]

\section{Results And Discussions}

\subsection{PCDD/F and DL-PCB levels in the sediments}

In this study, tThe linearity status, calibration curve equation, detection and quantification limits (LOD and LOQ) of the method used to measure PCDD/Fs and DL-PCBs concentration in sediments and tThe concentrations of each congener of PCDD/Fs and DL-PCBs in the sediments are presented in Table S2 and Table S3 in supplementary material. Total PCDD/Fs and DL-PCBs concentrations and corresponding TEQ values (based on WHO-2005 TEFs of the congeners) measured in the surface sediments are summarized in Table 3 . Total PCDD/Fs and DL-PCBs concentrations varied between 28.13-447.13 pg/g (average 136.75 pg/g) and 12.19-340.05 pg/g (average 72.09 $\mathrm{pg} / \mathrm{g}$ ), respectively. Corresponding TEQ values of PCDD/Fs and DL-PCBs were between 0.53-5.37 pg TEQ/g (average 2.23 pg TEQ/g) and 0.02-0.44 pg TEQ/g (average $0.12 \mathrm{pg} \mathrm{TEQ/g),} \mathrm{respectively.} \mathrm{The} \mathrm{sediments} \mathrm{taken} \mathrm{from} \mathrm{Kazandere} \mathrm{dam} \mathrm{have} \mathrm{the} \mathrm{lowest} \mathrm{pollution} \mathrm{levels} \mathrm{for}$ both PCDD/Fs and DL-PCBs. On the other hand, Alibey dam sediments have the highest PCDD/F concentrations while Elmalı dam sediments showed the highest DL-PCB concentrations.

Comparison of the results with the sediment data reported from other locations of the world shows that PCDD/F and DL-PCB levels in the dam lakes of Istanbul are not high and close to the values measured in the sediments collected from relatively unpolluted rivers, estuaries, and lakes (Isosaari et al., 2002; Norstrom, 2006; Nunes et al., 2011; Moon et al., 2012; Wang et al., 2016; Vandermarken et al., 2018; Ssebugere et al., 2019). In Turkey, only two studies were conducted on the PCDD/F pollution in the sediments: Okay et al. (2009) on PCB and PCDD/F levels in sediments and mussels of the Istanbul strait, and Karademir et al. (2014) on the PCDD/F levels in the sediments of the Izmit Bay.

Page $4 / 13$ 
Being close to dam lakes of concern in the study, pollution levels measured in sediments of Istanbul strait could be considered for comparison. Okay et al. (2009) gives the concentration levels of total PCBs and PCDD/Fs in sediments to be ranged from 17.9 to 539746 $\mathrm{pg} / \mathrm{g}$ and 2.04 to $60.5 \mathrm{pg} / \mathrm{g}$, respectively, while corresponding total WHO-TEQ values were between 0.01 and $17.8 \mathrm{pg}$ TEQ/g in sediments. It could be concluded that levels of dioxin-like compounds in sediments of the Istanbul strait and of the dam lakes of Istanbul are comparable, but it should be noted that these dams and lakes are used as the drinking water resources of Istanbul and they are legally protected by "By law on the Protection of Drinking and Domestic Water Basins" (RG, 2017). According to the by law, any type of wastewater or pollutant discharge to these water bodies is strictly prohibited and establishment and operation of any pollution creating activity is not allowed within all the basins. Therefore, pollution levels in these dam lakes should be assessed considering their importance as the principal drinking water resources for a 15-millions city.

[Table 3 near here]

For congener distributions of the PCDD/Fs in sediment samples, OCDD is the dominant congener by constituting about $75 \%$ of the total PCDD/Fs on average. Dominance of OCDD is typical in sediments and soils and is generally attributed to long term atmospheric deposition or accumulation processes (Nunes et al., 2011; Sanctorum et al., 2011; Moon et al., 2012). Same pattern has been observed in PCDD/F studies conducted in soils and sediments in Turkey also (Okay et al., 2009; Güzel et al., 2020). Especially, similarity of the congener distributions in the sediments of Istanbul strait given by Okay et al. (2009) and sediments of Istanbul dam lakes studied in this paper is apparent and remarkable (Fig. 3). Since wastewater discharges to dam lakes are prohibited by law, such high dominance of OCDD may be attributed to long term atmospheric deposition of these chemicals. Although the sediments from the strait showed lower PCDD/F levels, same congener distribution may indicate the same pollution source. High concentrations of OCDD in the atmosphere is generally linked to the various combustion facilities. USEPA (2006) states that OCDD is the dominant congener in the PCDD/F emissions of tire combustion, dieselfuelled and unleaded gas-fuelled vehicles, wood combustion, industrial oil fueled boilers, etc., while common use of some chlorinated pesticides, especially pentachlorophenol (PCP) could make additional contribution to OCDD levels in the environment also (Holt et al., 2008). The highest PCDD/F concentrations were measured in sediments of Alibey and Elmalı dams, which are the dams closest to highly populated settlements of Istanbul (see Fig. 1 and Table 1). Therefore, they are expected to be the dams that are most affected by the air pollution caused by the traffic and combustion for residential heating, confirming the assumption of atmospheric deposition as the principal source of PCDD/Fs in the sediments. DL-PCB congener distributions are similar also (Fig. 4), with the dominance of PCB-118 and PCB-105. Elmalı and Alibey dams had the highest DL-PCB concentrations in the sediments, as for PCDD/Fs.

[Figure 3 near here]

[Figure 4 near here]

Concerning the contributions of the congeners to total dioxin-like toxicity, PCDFs have the highest share with 57\%, while PCDDs and DL-PCBs constitute $38 \%$ and 5\%, respectively. Among PCDFs, 23478-PeCDF and 123478-HxCDF are responsible for about one third of the total TEQ on average, while 12378-PeCDD has the highest contribution among PCDDs. DL-PCBs constitute a small fraction of total TEQ (only 5\%), and $80 \%$ of total DL-PCB TEQ comes from PCB-126 due to its high TEF value, although its concentration is not high (Fig. 4).

\subsection{Environmental risk assessment}

Risk assessment of chemicals may be defined as the process of estimating and assessing the potential impact of a chemical, or a group of chemicals, on human health or ecological system for a given specific conditions and time. Ecological risk assessment (ERA) of chemicals is specifically related with determining the potential impact of chemicals to non-human organisms (flora and fauna) in the environment (Gatehouse, 2004), while health risk assessment (HRA) includes a complex methodology to estimate the health risks of the chemicals on humans via exposure pathways. Since contaminated sediments pose environmental risk for both aquatic biota (ecological) and people in contact with these sediments via direct or indirect exposure mechanisms (human health), a risk assessment methodology is applied based on the guidelines prepared by the Norwegian Environment Agency (NEA), i.e., "Risk Assessment of Contaminated Sediments-Guidelines" (NEA, 2018). The methodology given in the guidelines is adopted for estimating the risks of the contaminated sediments in Istanbul dam lakes, by considering the consumption of water as an additional exposure route, since these waterbodies are used as the water resource of Istanbul.

The assessment proposed is conducted in a tiered approach with three levels. Level 1 includes a simplified risk assessment in which the concentration of hazardous substances within the sediment, and the sediment toxicity, are compared with the threshold values for the ecological effects of contact with the sediment. For assessing PCDD/F and DL-PCB levels in the sediments, sediment quality guidelines (SQGs) developed by the Canadian Council of Ministers of the Environment (CCME) are used generally. CCME has two sets of guidelines termed the threshold effect level (TEL) and the probable effect level (PEL) for dioxins and dioxin-like chemicals, which are 0.85 and 21.5 pg TEQ/g, respectively (CCME, 2002). NEA (2018) proposes the threshold levels as $0.86 \mathrm{pg}$ TEQ/g for dioxin-like compounds (including PCDD/Fs and DL-PCBs) for insignificant risk in Level 1 (ecological risk only). As shown in Table 3, almost all the sediments studied here have dioxin- 
like toxicity levels higher than the threshold effect level (with two exceptions), but lower than the probable effect level, indicating that there could be ecological risk at some level. Moreover, Bhavsar et al. (2010) states that the CCME SQG, and most SQGs in general, were developed to protect aquatic benthic invertebrates only and do not consider adverse effects to higher trophic levels. Concerning that fish, other wildlife, and humans can be exposed to contaminants in the sediments through food web and consumption of benthic components of the food web, ecological risk assessment should also include the bioaccumulation of contaminants in fish and other trophic levels. Therefore, it could be concluded that levels of dioxin-like compounds in the sediments of Istanbul dam lakes are higher than the threshold levels proposed for insignificant ecological risk and a comprehensive ecological risk assessment including evaluation of the levels of these chemicals in freshwater biota in various trophic levels should be conducted.

Following the NEA methodology, since the results of the PCDD/F and d-PCB analyses show that exceedance of the threshold value is obvious for all the sampling stations, dam lakes can be considered as "contaminated". Then, if there is a link between the contaminated sediments and human health via some exposure pathways in the area, it is desirable to carry out a risk assessment related to human health. In that case, Level 2 must be performed, even if the area can be considered to pose acceptable ecological risk based on Level 1. Level 2 aims to determine the degree of health-related risk posed by contaminated sediments and includes three independent assessments: risk of spreading $(2 \mathrm{~A})$, risk to human health (2B) and risk of impact on the ecosystem (2C). Risk of spreading is related to transport of hazardous substances from the sediment to the water masses via diffusion and bioturbation, resuspension primarily because of ship traffic, and uptake by organisms and flow through the food web. Since the dams and lakes are not suitable for ships, and the use of any vehicles using fuel oil is prohibited by law for the protection of the water resources (only small-scale sailboats, oars or accumulator powered vessels and rafts are permitted), 2A assessment is not included here. Assessment of the human health risks (2B), on the other hand, is applied since these dams and lakes are used by the people living within their basins for recreational and fishing purposes. Moreover, since these freshwater bodies are water resources of Istanbul, "consumption of drinking water" becomes an additional exposure pathway with a certain degree of significance. Risk of impact on the ecosystem $(2 \mathrm{C})$ requires additional analysis and toxicity tests on the ecological matrices, which are beyond the scope of the study.

Human health risk assessment includes the determination of the relevant transport routes to humans based on how the sediment area is used. Therefore, site-specific evaluation of the exposure pathways is necessary to estimate health-related risks of contaminated sediments. Three main exposure routes are considered in the assessment:

a) Exposure through recreational facilities: Although dams and lakes of concern are not suitable for extensive swimming, people living in the immediate vicinity use them for recreational purposes in summer seasons. Since the worst-case scenario is considered in the assessment, swimming-related exposure pathways of i) ingestion of sediments, ii) ingestion of surface water, iii) ingestion of particulate matter, iv) human exposure via skin contact with sediment, and v) human exposure via skin contact with water are included.

b) Consumption of drinking water: As stated before, the dams and lakes are significant water resources protected by law, providing about half of the drinking and domestic water of 15-millions residents of Istanbul. It is known that PCDD/Fs and DL-PCBs have hydrophobic nature with very low water solubilities. Therefore, they are generally adsorbed on suspended or settled sediments in the water bodies, leading to very low concentrations in the water. Since suspended solids in freshwater are totally removed during the drinking water treatment processes, only the soluble fraction of the chemicals (which is expected to be extremely low) may enter the body via drinking water. Such exposure via drinking water is considered for the worst-case approach.

c) Consumption of fish: Since PCDD/Fs and DL-PCBs are lipophilic compounds accumulating in the fatty tissues of the animals and undergo bioaccumulation through the trophic levels, consumption of animal food is generally determined to be the major exposure route in the health risk assessment studies related to these compounds. Therefore, consumption of fish and other seafood is an important exposure pathway and is taken into account in the study. Since dams and lakes of concern are protected areas as drinking water resources, commercial fishing is prohibited by law, but sport fishing is very common in the area. Freshwater fishes such as carp, pike, rudd are the most common fishes found in these lakes and dams. Although the fish consumption is low in Turkey (TUIK, 2020) as compared to other coastal countries, it is included in the study with the assumption that all the fish consumed by the local people are caught in these lakes and dams.

Total daily exposure rates for dioxin-like compounds are calculated for child (6 years) and adult (64 years) separately and averaged over a lifetime of 70 years, as follows (Equation (1)):

$$
T C H=D E I_{s e d}+D E I_{s w}+D E I_{p m}+D E S_{s e d}+D E S_{s w}+I E I_{d w}+I E I_{f}
$$

1

where;

$\mathrm{TCH}=$ total daily exposure to sediment $(\mathrm{pg} / \mathrm{kg} / \mathrm{d})$,

$D E I_{\text {sed }}=$ direct exposure via oral ingestion of sediment $(\mathrm{pg} / \mathrm{kg} \mathrm{bw/d})$ 
$\mathrm{DEl}_{\mathrm{sw}}=$ direct exposure via oral ingestion of surface water $(\mathrm{pg} / \mathrm{kg} \mathrm{bw} / \mathrm{d})$

$\mathrm{DEI}_{\mathrm{pm}}=$ direct exposure via oral ingestion of particulate matter $(\mathrm{pg} / \mathrm{kg} \mathrm{bw} / \mathrm{d})$

$\mathrm{DES}_{\text {sed }}=$ exposure via skin contact with sediment $(\mathrm{pg} / \mathrm{kg} \mathrm{bw} / \mathrm{d})$

$\mathrm{DES}_{\mathrm{sw}}=$ exposure via skin contact with surface water $(\mathrm{pg} / \mathrm{kg} \mathrm{bw} / \mathrm{d})$

$\mathrm{IEI}_{\mathrm{dw}}=$ direct exposure via oral ingestion of drinking water $(\mathrm{pg} / \mathrm{kg} \mathrm{bw} / \mathrm{d})$

$\mathrm{IEI}_{\mathrm{f}}=$ direct exposure via oral ingestion of fish $(\mathrm{pg} / \mathrm{kg} \mathrm{bw} / \mathrm{d})$.

For concentrations of the dioxin-like compounds in the sediments, average TEQ-based concentration of $2.35 \mathrm{pg}$ TEQ/g is used to express total toxicity. Concentrations in the water, particulate matter and fish are estimated based on the methodology given in NEA (2018), which uses relevant partition coefficients (sediment-water) and bioconcentration/bioaccumulation factors (water-biota or sediment-biota) for dioxinlike compounds. Organic carbon fraction of the sediments used in the calculations is measured as $2.26 \%$ on average (0.63-4.29\%). All the exposure parameters are taken from NEA (2018) also, except for drinking water and fish consumption routes. For the exposure via drinking water, calculated water concentrations and ingestion rates of 1 and 2 liters per day for child and adult are used respectively. For consumption of local fish, consumption rates of 0.01 and $0.01 \mathrm{~kg}$ per day are used for child and adult, respectively, concerning that average fish consumption in Turkey is $6.3 \mathrm{~kg}$ per capita per year (TÜiK, 2020). The results of health risk assessment applied are summarized in Table 4.

[Table 4 near here]

Considering total doses of dioxin-like compounds for humans, threshold value of $1 \mathrm{pg}$ TEQ/kg body weight/day is generally assumed as acceptable or tolerable in national and international guidelines. Health risk assessment applied here for the contaminated sediments shows that levels of dioxin-like compounds would result in a total intake of $0.33 \mathrm{pg} \mathrm{TEQ} / \mathrm{kg}$ bw/day even in the worst-case scenario, not exceeding the tolerable daily intake value. As it is expected, consumption of fish constitutes almost all the total intake, while contributions of other pathways are minimal. But it should be noted that fish consumption is not the only pathway, and the threshold value may be exceeded when the intakes from other animal or plant food with local or commercial origin (and direct inhalation of polluted air) are added. Therefore, conducting a more detailed risk assessment including the determination of dioxin-like compounds in air, plant and animal foods and fishes (local and commercial) would be more appropriate to assess the risks posed by these compounds for the humans.

\section{Conclusions}

The study includes an assessment of PCDD/F and DL-PCB concentrations in the sediments of Istanbul dams and lakes, which provide about half of the drinking and domestic water of the city. Following conclusions could be attained from evaluation of the results:

- Almost all the sediments have total dioxin-like toxicity levels higher than the safe threshold level (with two exceptions) of $0.85 \mathrm{pg}$ TEQ/g $\mathrm{dw}$, proposed for insignificant ecological risk and therefore, a comprehensive ecological risk assessment including evaluation of the levels of these chemicals in freshwater biota in various trophic levels should be conducted.

- OCDD is the dominant congener by constituting about 75\% of the total PCDD/Fs on average, which may be attributed to long term atmospheric deposition or accumulation processes. Congener distributions of DL-PCBs showed the dominance of PCB-118 and PCB105.

- The highest PCDD/F and DL-PCB concentrations were measured in sediments of Alibey and Elmalı dams, which are the dams closest to highly populated settlements of Istanbul. Therefore, they are expected to be the dams that are most affected by the air pollution caused by the traffic and combustion for residential heating, confirming the assumption of atmospheric deposition as the principal source of these compounds in the sediments.

- Since the dams and lakes are significant water resources for Istanbul, a risk assessment study is conducted to estimate the health risks posed by these contaminated sediments via different exposure routes. Health risk assessment shows that levels of dioxin-like compounds would result in a total intake of $0.33 \mathrm{pg}$ TEQ/ $\mathrm{kg}$ bw/day even in the worst-case scenario, not exceeding the tolerable daily intake value of $1 \mathrm{pg}$ TEQ/kg bw/day. Among exposure pathways, consumption of fish constitutes almost all the total intake, while contributions of other pathways are minimal.

- Considering other exposure pathways that are not related with the sediments, more detailed risk assessment including the determination of dioxin-like compounds in air, plant and animal foods and fishes (local and commercial) is proposed to assess the risks posed by these compounds for the humans.

Page $7 / 13$ 


\section{Declarations}

\section{Acknowledgements}

The authors wish to thank scholarship Beyza YÜCE for their supports in the laboratory studies.

\section{Author contribution}

Barış GUZEL: Supervision, Data curation, Formal analysis, Investigation, Writing - original draft, Writing - review \& editing. Oltan CANLI: Conceptualization, Data curation, Investigation, Writing - review \& editing. Aykan KARADEMIR Data curation, Formal analysis, Investigation, Writing - original draft, Writing - review \& editing.

\section{Data availability}

Not applicable.

\section{Ethics approval and consent to participate}

Not applicable.

\section{Consent for publication}

Not applicable.

\section{Funding}

Not applicable.

\section{Competing interests}

The authors declare no competing interests.

\section{References}

1. Altinbilek D (2006) Water Management in Istanbul. Water Resour Dev 22(2):241-253

2. Baban A, Tayfur G (2011) Groundwater contamination and its effect on health in Turkey. Environ Monit Assess 183(4):77-94

3. Bhavsar SP, Gewurtz SB, Helm PA, Labencki TL, Marvin CH, Fletcher R, Hayton A, Reiner EJ, Boyd D (2010) Estimating Sediment Quality Thresholds to Prevent Restrictions on Fish Consumption: Application to Polychlorinated Biphenyls and Dioxins-Furans in the Canadian Great Lakes. Integrated Environmental Assessment and Management, Volume 6, Number 4, 641-652

4. CCME (2002) Canadian Council of Ministers of the Environment.Canadian Environmental Quality Guidelines, vol. 2

5. Dinç B, Avaz G, Canlı O, Güzel B, Eren B, Yetiş Ü (2021) Evaluation of organochlorine pesticides (OCPs) and polychlorinated biphenyls (PCBs) concentrations in the river and marine sediments of Samsun coastline. J Water Chem Technol 43:131-138

6. Evenset E, Christensen GN, Carrol J, Zaborska A, Berger U, Herzke D, Gregor D (2007) Historical trends in persistent organic pollutants and metals recorded in sediment from lake Ellasjøen, Bjørnøya, Norwegian Arctic. Environ Pollut 146:196-205

7. Field JA, Sierra-Alvarez R (2008)Microbial degradation of chlorinated dioxins. Chemosphere (6),1005-18

8. Gatehouse R (2004) Ecological Risk Assessment of Dioxins in Australia, National Dioxins Program Technical Report No. 11, Australian Government Department of the Environment and Heritage, Canberra

9. Güzel B, Canli O, Aslan A (2022) Spatial distribution, source identification and ecological risk assessment of POPs and heavy metals in lake sediments of Istanbul, Turkey. Mar Pollut Bull 113172. https://doi.org/10.1016/j.marpolbul.2021.113172

10. Güzel B, Canli O, Dede Ş, Karademir A (2020) Assessment of PCDD/F and dioxin-like PCB levels in environmental and food samples in the vicinity of IZAYDAS waste incinerator plant (WIP): from past to present. Environ Sci Pollut Res 27:13902-13914

11. Holt E, Von der Recke R, Wetter W, Hawker D, Alberts V, Kuch B, Weber R, Gaus C (2008) Assessing dioxin precursors in pesticide formulations and environmental samples as a source of octachlorodibenzop-dioxin in soil and sediment. Environ Sci Technol 42:14721478

12. Hung W, Huang WY, Lin C, Vu CT, Yotapukdee S, Kaewlaoyoong A, Chen JR, Shen YH (2017) The use of ultrasound-assisted anaerobic compost tea washing to remove poly-chlorinated dibenzo-p-dioxins (PCDDs), dibenzo-furans (PCDFs) from highly contaminated field soils. Environ Sci Pollut Res Int 24:18936-18945 
13. ISKI (2021) İçilebilir Su Serüveni - Su Kaynakları. Accessed on Jan 30, 2021 at https://www.iski.istanbul/web/tr-TR/kurumsal/iskihakkinda1/su-kaynaklari1

14. Isosaari P, Pajunen H, Vartiainen T (2002) PCDD/F and PCB history in dated sediments of a rural lake. Chemosphere 47:575-583

15. Jaishankar M, Tseten T, Anbalagan N, Mathew BB, Beeregowda KN (2014) Toxicity, mechanism and health effects of some heavy metals. Interdiscip Toxicol 7:60-72

16. Karademir A, Ergül HA, Telli B, Kilavuz SA, Terzi M (2014) Evaluation of PCDD/F pollution in surface sediments of Izmit Bay. Environ Sci Pollut Res 20(9):6611-6619

17. Kulkarni PS, Crespo JG, Afonso CAM (2008) Dioxins sources and current remediation technologies - A review. Environ Int 34:139-153

18. Li H, Yu L, Sheng G, Fu J, Peng P (2007) Severe PCDD/F and PBDD/F pollution in air around an electronic waste dismantling area in China. Environ Sci Technol 41(16):5641-5646

19. Lin C, Kaewlaoyoong A, Vu CT, Huang WY (2017) Treatment of dioxin-contaminated soil by organic waste co-composting system. International Conference on Physics and Mechanics of New Materials and Their Applications PHENMA Advanced Materials, pp. 619623

20. Moon HB, Choi M, Choi HG, Kannan K (2012) Severe pollution of PCDD/Fs and dioxin-like PCBs in sediments from Lake Shihwa, Korea: Tracking the source. Mar Pollut Bull 64(11):2357-2363

21. NEA (2018) Risk assessment of contaminated sediments - Guidelines. Norwegian Environmental Agency. Guidance Notes M-1132

22. Nguyen HL, Leermakers M, Osan J, Török S, Baeyens W (2005) Heavy metals in Lake Balaton: water column, suspended matter, sediment and biota. Sci Total Environ 340(1-3):213-230

23. Norstrom RJ (2006) Polychlorinated dibenzo-p-dioxins and dibenzofurans in the Great Lakes. Hdb Env Chem 5:71-150

24. Nunes M, Marchand P, Vernisseau A, Le Bizec B, Ramos F, Pardal MA (2011) PCDD/Fs and dioxin-like PCBs in sediment and biota from the Mondego estuary (Portugal). Chemosphere 83(10):1345-1352

25. Okay OS, Karacık B, Başak S, Henkelmann B, Bernhöft S, Schramm KW (2009) PCB and PCDD/F in sediments and mussels of the Istanbul strait (Turkey). Chemosphere 76:159-166

26. RG (2017) Bylaw on the Protection of Drinking and Domestic Water Basins. Resmi Gazete 30224-28.10.2017, (in Turkish)

27. Sanctorum H, Elskens M, Leermakers M, Gao Y, Charriau A, Billon G, Goscinny S, De Cooman W, Baeyens W (2011) Sources of PCDD/Fs, non-ortho PCBs and PAHs in sediments of high and low impacted transboundary rivers (Belgium-France). Chemosphere 85(2):203-209

28. Sany SB, Hashim R, Rezayi M, Rahman MA, Razavizadeh BB, Abouzari-lotf E, Karlen DJ (2015) Integrated ecological risk assessment of dioxin compounds. Environ Sci Pollut Res Int 2:11193-11208

29. Shaw SD, Berger ML, Weijs L, P€ apke O, Covaci A (2014) Polychlorinated biphenyls still pose significant health risks to northwest Atlantic harbor seals. Sci Total Environ 490:477-487

30. Song A, Li H, Liu MY, Peng P, Hu JF, Sheng G, Ying G022. Polybrominated dibenzo-p-dioxins/furans (PBDD/Fs) in soil around municipal solid waste incinerator: A comparison with polychlorinated dibenzo-p-dioxins/furans (PCDD/Fs).Environ. Pollut.118563

31. Ssebugere P, Sillanpaa M, Matovu H, Mubiru E (2019) Human and environmental exposure to PCDD/Fs and dioxin-like PCBs in Africa: A review. Chemosphere 223:483-493

32. Suzuki G, Someya M, Matsukami H, Tue NM, Uchida N, Tuyen LH, Viet PH, Takahashi S, Tanabe S, Brouwer A, Takigami H (2016) Comprehensive evaluation of dioxins and dioxin-like compounds in surface soils and river sediments from e-waste-processing sites in a village in northern Vietnam: heading towards the environmentally sound management of e-waste. Emerg Contam 2:98-108

33. TÜiK (2020) Turkish Statistical Institute, Seafood Statistics 2020 (in Turkish)

34. Unalan D (2011) Why cities cannot be sustainable: Governance and planning for Istanbul. Local Econ 26(4):305-313

35. USEPA (2006) An Inventory of Sources and Environmental Releases of Dioxin-Like Compounds in the United States for the Years 1987, 1995, and 2000. EPA/600/P-03/002F

36. Vandermarken T, Gao Y, Baeyens W, Denison MS, Croes K (2018) Dioxins, furans and dioxin-like PCBs in sediment samples and suspended particulate matter from the Scheldt estuary and the North Sea Coast: Comparison of CALUX concentration levels in historical and recent samples. Sci Total Environ 1(626):109-116

37. Wang P, Shang H, Li H, Wang Y, Li Y, Zhang H, Zhang Q, Liang Y, Jiang G (2016) PBDEs, PCBs and PCDD/Fs in the sediments from seven major river basins in China: Occurrence, congener profile and spatial tendency. Chemosphere 144:13-20

\section{Tables}


Table 1

The geographical locations of the sampling points in Istanbul dam lakes

\begin{tabular}{|c|c|c|c|c|}
\hline \multirow[t]{2}{*}{ Site Code } & \multirow[t]{2}{*}{ Dam Name } & \multicolumn{3}{|l|}{ Site Location } \\
\hline & & Latitude & Longitude & Sampling Date \\
\hline IS-1 & Terkos Dam & $41^{\circ} 22^{\prime} 26.10^{\prime \prime} \mathrm{N}$ & $28^{\circ} 31^{\prime} 52.90^{\prime \prime} \mathrm{E}$ & 12.10 .2020 \\
\hline IS-2 & Terkos Dam & $41^{\circ} 19^{\prime} 53.50^{\prime \prime} \mathrm{N}$ & $28^{\circ} 33^{\prime} 47.38^{\prime \prime} \mathrm{E}$ & 12.10 .2020 \\
\hline IS-3 & Terkos Dam & $41^{\circ} 20^{\prime} 7.93^{\prime \prime} \mathrm{N}$ & $28^{\circ} 35^{\prime} 38.99^{\prime \prime} \mathrm{E}$ & 12.10 .2020 \\
\hline IS-4 & Büyükcekmece Dam & $41^{\circ} 5^{\prime} 25.00^{\prime \prime} \mathrm{N}$ & $28^{\circ} 32^{\prime} 52.70^{\prime \prime} \mathrm{E}$ & 12.10 .2020 \\
\hline IS-5 & Büyükcekmece Dam & $41^{\circ} 4^{\prime} 1.63^{\prime \prime} \mathrm{N}$ & $28^{\circ} 33^{\prime} 21.73^{\prime \prime} \mathrm{E}$ & 12.10 .2020 \\
\hline IS-6 & Büyükcekmece Dam & $41^{\circ} 2^{\prime} 8.46^{\prime \prime} \mathrm{N}$ & $28^{\circ} 34^{\prime} 19.12^{\prime \prime} \mathrm{E}$ & 12.10 .2020 \\
\hline IS-7 & Elmalı Dam & $41^{\circ} 4^{\prime} 14.20^{\prime \prime} \mathrm{N}$ & $29^{\circ} 7^{\prime} 20.40^{\prime \prime} \mathrm{E}$ & 14.10 .2020 \\
\hline IS-8 & Elmalı Dam & $41^{\circ} 4^{\prime} 37.87^{\prime \prime} \mathrm{N}$ & $29^{\circ} 7^{\prime} 11.27^{\prime \prime} \mathrm{E}$ & 14.10 .2020 \\
\hline IS-9 & Darlık Dam & $41^{\circ} 6^{\prime} 26.47^{\prime \prime} \mathrm{N}$ & $29^{\circ} 33^{\prime} 49.82^{\prime \prime} \mathrm{E}$ & 14.10.2020 \\
\hline IS-10 & Darlık Dam & $41^{\circ} 5^{\prime} 47.68^{\prime \prime} \mathrm{N}$ & $29^{\circ} 34^{\prime} 29.04^{\prime \prime} \mathrm{E}$ & 14.10 .2020 \\
\hline IS-11 & Darlık Dam & $41^{\circ} 4^{\prime} 13.84^{\prime \prime} \mathrm{N}$ & $29^{\circ} 35^{\prime} 18.23^{\prime \prime} \mathrm{E}$ & 14.10 .2020 \\
\hline IS-12 & Kazandere Dam & $41^{\circ} 36^{\prime} 52.61^{\prime \prime} \mathrm{N}$ & $28^{\circ} 4^{\prime} 12.54^{\prime \prime} \mathrm{E}$ & 14.10 .2020 \\
\hline IS-13 & Kazandere Dam & $41^{\circ} 37^{\prime} 6.89^{\prime \prime} \mathrm{N}$ & $28^{\circ} 3^{\prime} 10.67^{\prime \prime} \mathrm{E}$ & 14.10 .2020 \\
\hline IS-14 & Sazlıdere Dam & $41^{\circ} 6^{\prime} 50.70^{\prime \prime} \mathrm{N}$ & $28^{\circ} 43^{\prime} 37.58^{\prime \prime} \mathrm{E}$ & 13.10 .2020 \\
\hline IS-15 & Sazlıdere Dam & $41^{\circ} 7^{\prime} 3.06^{\prime \prime} \mathrm{N}$ & $28^{\circ} 41^{\prime} 21.62^{\prime \prime} \mathrm{E}$ & 13.10.2020 \\
\hline IS-16 & Sazlıdere Dam & $41^{\circ} 8^{\prime} 28.80^{\prime \prime} \mathrm{N}$ & $28^{\circ} 40^{\prime} 30,70^{\prime \prime} \mathrm{E}$ & 13.10.2020 \\
\hline IS-17 & Papucdere Dam & $41^{\circ} 39^{\prime} 20.89^{\prime \prime} \mathrm{N}$ & $28^{\circ} 1^{\prime} 49.51^{\prime \prime} \mathrm{E}$ & 12.10 .2020 \\
\hline IS-18 & Papucdere Dam & $41^{\circ} 38^{\prime} 17.71^{\prime \prime} \mathrm{N}$ & $28^{\circ} 3^{\prime} 29.54^{\prime \prime} \mathrm{E}$ & 12.10 .2020 \\
\hline IS-19 & Alibey Dam & $41^{\circ} 6^{\prime} 12.05^{\prime \prime} \mathrm{N}$ & $28^{\circ} 55^{\prime} 15.07^{\prime \prime} \mathrm{E}$ & 13.10 .2020 \\
\hline IS-20 & Alibey Dam & $41^{\circ} 8^{\prime} 9.10^{\prime \prime} \mathrm{N}$ & $28^{\circ} 53^{\prime} 39.00^{\prime \prime} \mathrm{E}$ & 13.10 .2020 \\
\hline IS-21 & Ömerli Dam & $41^{\circ} 3^{\prime} 28.26^{\prime \prime} \mathrm{N}$ & $29^{\circ} 22^{\prime} 8.29^{\prime \prime} \mathrm{E}$ & 13.10 .2020 \\
\hline IS-22 & Ömerli Dam & $41^{\circ} 4^{\prime} 19.24^{\prime \prime} \mathrm{N}$ & $29^{\circ} 23^{\prime} 15.37^{\prime \prime} \mathrm{E}$ & 13.10.2020 \\
\hline IS-23 & Ömerli Dam & $41^{\circ} 2^{\prime} 51.62^{\prime \prime} \mathrm{N}$ & $29^{\circ} 23^{\prime} 2.29^{\prime \prime} \mathrm{E}$ & 13.10 .2020 \\
\hline
\end{tabular}


Table 2

GC program for the determination of PCDD/Fs and DL-PCBs

\begin{tabular}{|c|c|c|c|}
\hline \multicolumn{4}{|l|}{ Parameters } \\
\hline Carrier Gas & \multicolumn{3}{|c|}{ Helium } \\
\hline Carrier Gas Flow & \multicolumn{3}{|c|}{$1.0 \mathrm{~mL} / \mathrm{min}$. } \\
\hline Column Type & \multicolumn{3}{|c|}{ DB-5MS Capillary Column } \\
\hline Column Length & \multicolumn{3}{|l|}{$60 \mathrm{~m}$} \\
\hline Column Inner Diameter & \multicolumn{3}{|c|}{$0.25 \mathrm{~mm}$} \\
\hline Film Thickness & \multicolumn{3}{|c|}{$0.25 \mu \mathrm{m}$} \\
\hline Detector Type & \multicolumn{3}{|c|}{ HR-MS } \\
\hline Source Temperature & \multicolumn{3}{|l|}{$260^{\circ} \mathrm{C}$} \\
\hline Electron Energy & \multicolumn{3}{|l|}{$45 \mathrm{eV}$} \\
\hline Ionization Mode & \multicolumn{3}{|c|}{ Electron Impact (El+) } \\
\hline Acquisition Mode & \multicolumn{3}{|c|}{ Voltage SIR (quantitative analysis) } \\
\hline Injection Volume & \multicolumn{3}{|c|}{$2 \mu \mathrm{L}$ splitless } \\
\hline Resolution & \multicolumn{3}{|c|}{10,000 (5\% height, $10 \%$ valley) } \\
\hline \multicolumn{4}{|c|}{$"$} \\
\hline Oven Temperature Program (PCDD/Fs) & Ratio ( $\left.{ }^{\circ} \mathrm{C} / \mathrm{min}\right)$ & Temperature $\left({ }^{\circ} \mathrm{C}\right)$ & Hold Time (min.) \\
\hline \multirow[t]{4}{*}{ Initial } & & 140 & 3 \\
\hline & 15 & 200 & 0 \\
\hline & 3 & 235 & 15 \\
\hline & 4 & 300 & 10 \\
\hline \multirow[t]{2}{*}{ Purge Temperature } & \multicolumn{3}{|l|}{$300^{\circ} \mathrm{C}$} \\
\hline & \multicolumn{3}{|l|}{ Süre } \\
\hline Purge Time & \multicolumn{3}{|l|}{$4 \mathrm{~min}}$. \\
\hline Purge Flow & \multicolumn{3}{|l|}{$30 \mathrm{~mL} / \mathrm{min}$} \\
\hline Oven Temperature Program (DL-PCBs) & Ratio ( $\left.{ }^{\circ} \mathrm{C} / \mathrm{min}\right)$ & Temperature $\left({ }^{\circ} \mathrm{C}\right)$ & Hold Time (min.) \\
\hline \multirow[t]{5}{*}{ Initial } & & 140 & 2 \\
\hline & 40 & 220 & 0 \\
\hline & 1 & 230 & 11 \\
\hline & 20 & 250 & 0 \\
\hline & 5 & 300 & 5 \\
\hline \multirow[t]{2}{*}{ Purge Temperature } & \multicolumn{3}{|l|}{$300^{\circ} \mathrm{C}$} \\
\hline & \multicolumn{3}{|l|}{ Süre } \\
\hline Purge Time & \multicolumn{3}{|l|}{$2 \mathrm{~min}$} \\
\hline Purge Flow & \multicolumn{3}{|l|}{$50 \mathrm{~mL} / \mathrm{min}$} \\
\hline
\end{tabular}

Table 3.Total PCDD/F and DL-PCB concentrations $(\mathrm{pg} / \mathrm{g})$ in the sediments of Istanbul dam lakes 


\begin{tabular}{|c|c|c|c|c|c|c|c|c|c|c|c|c|c|}
\hline & \multicolumn{3}{|c|}{ Terkos Lake } & \multicolumn{3}{|c|}{ Büyükçekmece Dam } & \multicolumn{2}{|c|}{ Elmalı Dam } & \multicolumn{2}{|c|}{ Darlık Dam } & \multirow[b]{2}{*}{ IS-11 } & \multicolumn{2}{|c|}{$\begin{array}{l}\text { Kazandere } \\
\text { Dam }\end{array}$} \\
\hline $\begin{array}{l}\text { Sample } \\
\text { No: }\end{array}$ & IS-1 & IS-2 & IS-3 & IS-4 & IS-5 & IS-6 & IS-7 & IS-8 & IS-9 & IS-10 & & IS-12 & IS-13 \\
\hline $\begin{array}{l}\text { Total } \\
\text { PCDFs }\end{array}$ & 13.12 & 16.58 & 8.96 & 7.53 & 8.06 & 15.82 & 28.78 & 19.03 & 25.17 & 17.54 & 9.51 & 4.28 & 10.30 \\
\hline $\begin{array}{l}\text { Total } \\
\text { PCDDs }\end{array}$ & 178.32 & 73.91 & 64.93 & 62.28 & 99.90 & 133.23 & 59.35 & 53.33 & 432.23 & 171.86 & 19.33 & 23.85 & 67.20 \\
\hline $\begin{array}{l}\text { Total } \\
\text { PCDD/Fs }\end{array}$ & 191.44 & 90.50 & 73.89 & 69.81 & 107.96 & 149.04 & 88.13 & 72.36 & 457.39 & 189.41 & 28.85 & 28.13 & 77.49 \\
\hline $\begin{array}{l}\text { Total DL- } \\
\text { PCBs }\end{array}$ & 43.10 & 47.92 & 53.92 & 25.35 & 50.25 & 36.46 & 340.05 & 237.12 & 67.74 & 42.70 & 45.82 & 12.19 & 36.83 \\
\hline $\begin{array}{l}\text { WHO- } \\
\text { TEQ }_{\text {PCFD }}\end{array}$ & 1.08 & 1.08 & 0.68 & 0.65 & 0.7 & 1.23 & 2.55 & 1.64 & 1.97 & 1.37 & 0.73 & 0.33 & 0.76 \\
\hline $\begin{array}{l}\text { WHO- } \\
\text { TEQ }\end{array}$ & 1.06 & 0.58 & 0.44 & 0.88 & 0.91 & 1.59 & 0.69 & 0.53 & 2.02 & 0.89 & 0.26 & 0.2 & 0.47 \\
\hline $\begin{array}{l}\text { WHO- } \\
\text { TEQ } \\
\text { PCDD/F }\end{array}$ & 2.14 & 1.66 & 1.12 & 1.53 & 1.61 & 2.82 & 3.24 & 2.17 & 3.99 & 2.26 & 0.99 & 0.53 & 1.23 \\
\hline $\begin{array}{l}\text { WHO- } \\
\text { TEQ }_{\text {DL-PCB }}\end{array}$ & 0.02 & 0.09 & 0.05 & 0.05 & 0.44 & 0.07 & 0.40 & 0.38 & 0.11 & 0.10 & 0.05 & 0.02 & 0.06 \\
\hline $\begin{array}{l}\text { WHO- } \\
\text { TEQ }_{\text {Total }}\end{array}$ & 2.16 & 1.75 & 1.17 & 1.58 & 2.05 & 2.89 & 3.64 & 2.55 & 4.10 & 2.36 & 1.04 & 0.55 & 1.29 \\
\hline
\end{tabular}

\begin{tabular}{|c|c|c|c|c|c|c|c|c|c|c|c|}
\hline \multirow[b]{2}{*}{ Sample No: } & \multicolumn{3}{|c|}{ Sazlıdere Dam } & \multicolumn{2}{|c|}{ Papuçdere Dam } & \multicolumn{2}{|c|}{ Alibey Dam } & \multicolumn{3}{|c|}{ Ömerli Dam } & \multirow[t]{2}{*}{ Average } \\
\hline & IS-14 & IS-15 & IS-16 & IS-17 & IS-18 & IS-19 & IS-20 & IS-21 & IS-22 & IS-23 & \\
\hline Total PCDFs & 21.93 & 28.63 & 13.60 & 7.47 & 14.09 & 28.99 & 14.88 & 25.70 & 7.00 & 17.77 & 15.86 \\
\hline Total PCDDs & 79.53 & 91.47 & 44.55 & 93.31 & 153.27 & 147.02 & 432.25 & 95.54 & 22.60 & 181.20 & 120.89 \\
\hline Total PCDD/Fs & 101.45 & 120.09 & 58.15 & 100.77 & 167.37 & 176.00 & 447.13 & 121.24 & 29.60 & 198.96 & 136.75 \\
\hline Total DL-PCBs & 61.04 & 49.41 & 66.86 & 29.78 & 36.49 & 101.45 & 53.46 & 117.14 & 26.43 & 76.54 & 72.09 \\
\hline WHO-TEQ & 1.84 & 2.39 & 1.12 & 0.59 & 1.09 & 2.53 & 1.2 & 1.96 & 0.45 & 1.37 & 1.27 \\
\hline WHO-TEQ & 0.87 & 0.92 & 0.63 & 0.39 & 0.58 & 1.99 & 4.17 & 0.73 & 0.18 & 0.91 & 0.95 \\
\hline$W_{H O}-T E Q_{P C D D / F}$ & 2.71 & 3.31 & 1.75 & 0.98 & 1.67 & 4.52 & 5.37 & 2.69 & 0.63 & 2.28 & 2.23 \\
\hline$W{ }^{-}-T_{D L-P C B}$ & 0.12 & 0.10 & 0.17 & 0.04 & 0.05 & 0.17 & 0.08 & 0.14 & 0.04 & 0.09 & 0.12 \\
\hline $\mathrm{WHO}^{-T E Q_{\text {Total }}}$ & 2.83 & 3.41 & 1.92 & 1.02 & 1.72 & 4.69 & 5.45 & 2.83 & 0.67 & 2.37 & 2.35 \\
\hline
\end{tabular}

Table 4. Estimated dioxin-like toxicity doses for humans from contaminated sediments of Istanbul dam lakes (pg/kg bw/day; percentages show contribution to total value) 


\begin{tabular}{|lll|}
\hline Exposure Pathway & Child & Adult \\
\hline Ingestion of sediments & $1.29 \mathrm{E}-02(2 \%)$ & $9.66 \mathrm{E}-04$ \\
\hline Ingestion of surface water & $1.32 \mathrm{E}-05$ & $2.82 \mathrm{E}-06$ \\
\hline Ingestion of particulate matter & $3.86 \mathrm{E}-05$ & $2.82 \mathrm{E}-06$ \\
\hline Human exposure via skin contact with sediment & $1.34 \mathrm{E}-03$ & $1.74 \mathrm{E}-03(1 \%)$ \\
\hline Human exposure via skin contact with water & $2.08 \mathrm{E}-09$ & $4.22 \mathrm{E}-10$ \\
\hline Drinking water consumption & $3.20 \mathrm{E}-03(0.5 \%)$ & $1.37 \mathrm{E}-03$ \\
\hline Fish consumption & $6.72 \mathrm{E}-01$ (97\%) & $2.88 \mathrm{E}-01$ (99\%) \\
\hline Total & $6.89 \mathrm{E}-01$ & $\mathbf{2 . 9 2 E - 0 1}$ \\
\hline Lifetime Dose & $3.26 \mathrm{E}-01$ & \\
\hline
\end{tabular}

\section{Figures}

\section{Figure 1}

Satellite display of sampling points (Source: Google Earth)

\section{Figure 2}

GC chromatograms of a) 123478-HxCDF for PCDD/Fs and b) PCB 167 for DL-PCBs

\section{Figure 3}

PCDD/F congener distributions in the sediments of Istanbul strait (reproduced from data given by Okay et al., 2009) and Istanbul dam lakes

\section{Figure 4}

DL-PCB congener distributions in the sediments of Istanbul strait (reproduced from data given by Okay et al., 2009) and Istanbul dam lakes

\section{Supplementary Files}

This is a list of supplementary files associated with this preprint. Click to download.

- ElectronicSupplementaryMaterial.docx 